\title{
Graphic Translation of Experimental Verse as a Strategy of Poetic Text's Transcreation
}

\section{Vladimir Feshchenko*}

\begin{abstract}
The article examines the problem of translating experimental poetic texts into other languages. The focus is on the transfer of verse's spatial design between the source and the target languages. We analyze some cases of unconventional poetry translation with particular attention to verbal/visual properties of avant-garde poems. Stéphane Mallarmés, Guillaume Apollinaire's, Augusto de Campos' and Dmitry A. Prigov's visual poetry provides examples of autographic (hand-written or hand-drawn) and allographic (typewritten or typeset) texts. The former, as we argue, are problematic for translation, just like pictures in painting, whereas the latter may be rendered in another language. The analysis of E. E. Cummings' allographic experimental verse allows to propose a special strategy for translating this kind of texts. By analogy with 'phonetic translation', this strategy can be called 'graphic translation'. This type of translation preserves the visual and metagraphemic forms of the original text, rearranging its lexical elements in translation. It specifically applies to visually-oriented avant-garde and experimental texts. Graphic translation 'transcreates' the text to a certain degree and this contributes to preserve and reinforce the experimental nature of avant-garde verse in languages other than its own.
\end{abstract}

Keywords: experimental poetry; spatial design; graphic translation; autographic/allographic text

In translation theory as well as in poetics, scholars have paid little attention so far to the transfer of verse design between the source and the target languages. Even well-grounded books on poetry translation, such as Andrea Kenesei's reader (2010), for example, lack a chapter on verbal/visual intercrossings. The translation scholar Lawrence Venuti only mentions this issue passingly in his introductory article on poetry translation (2011). Meanwhile, practicing translators constantly face this problem, especially in translating from non-cognate languages or languages with different writing systems.

For forms of experimental verse oriented towards specifically visual means, apart from verbal elements, Marjorie Perloff's (2010: 69) term spatial design

\footnotetext{
* Author's address: Vladimir Feshchenko, The Institute of Linguistics of the Russian Academy
} of Sciences, Bolshoi Kislovsky pereulok, Moscow 125009, Russia. Email: takovich2@gmail.com. 
could be applicable. The spatial design of verse would mean the location of the text on the page, its configuration and the quantitative ratio of the text lengths and spaces, as well as its font-specific and punctuation characteristics. Spatial design is not simply a means of expression, but also a way to create rhythm and, eventually, to make sense. According to Katherine McCoy, graphic design in general is deeply involved with the problem of meaning and "the twentieth century has seen radical realignments in our assumptions of how functional printed forms and how 'art forms' communicate through words and images" (1988: 116). In what follows we will analyze some cases of unconventional poetry translation with particular attention to verbal/visual properties of avant-garde poems in the source and target languages. The central focus of the article is on how non-conventional spatial design in poetry can be transferred into another language.

Avant-garde poetry of the early twentieth century started to experiment with all linguistic and extralinguistic levels of verse, including the visual (graphic) plane. Experimental verse suggested a deformation of the poem's structure as a system of signs and, particularly, a deformation of iconicity as a property of a linguistic sign (see the pioneering article Nänny 1986). As the Russian futurist poet Velimir Khlebnikov put it, "the word followed boldly after painting". To be more precise, the word followed abstract painting that broke up with pictorial conventions. This transition, or revolution, is most clearly visible in the case of poetic texts written by painters, such as Wassily Kandinsky who composed abstract verse to accompany his graphic art. Poems from his album Sounds deviate from the classical line-and-stanza verse forms. Yet these graphic experiments still remain quite impressionistic and do not pose a problem for translation. Kandinsky himself could easily indulge in self-translation of his own poems between two of his native tongues, Russian and German.

Things get more complicated in translating radical avant-garde poetry that involved deformations on the level of metagraphemics. Natalia Fateeva defines metagraphemics as "the means and ways of the written text's arrangement, which are complementary to the usual recording of a verbal message" (2010: 304). Regular (unmarked) recording of the text becomes obsolete; graphic markedness creates new semantics and new pragmatics of the avant-garde text. 


\section{Stéphane Mallarmé and Guillaume Apollinaire:} allographic vs. autographic text in translation

Stéphane Mallarmé (1842-1898) was the first poet who, long before the historical avant-garde, intentionally used metagraphemics. What happens in his poem A Roll of the Dice? The words abandon their usual positions in traditional poetic meter and scatter all across the page in various constellations. However, this scattering is not arbitrary. The new positions taken by words and phrases between numerous spaces and indents trigger new mechanisms of semantic association and coherence (as brilliantly analyzed in Kristeva 1974). Characteristically, the first translations of this poem into foreign languages followed the traditional strategy of translating horizontally "line after line", from left to right, from top to bottom. These first translators followed classical techniques of reading poetry. In our times, over the last few years, $A$ Roll of the Dice appeared in at least two new and innovative translations (Mallarmé 2014, 2015). They go far beyond traditional techniques, in dissociating the text's cohesion in the target text, which bridges Mallarmé with contemporary poetry (cf. Figure 1 - an excerpt from Kirill Korchagin's new translation of Un coup de dès into Russian - with Figure 2, a fragment of Ivan Sokolov's recent visual poem).

A series of poems under the title Calligrams by Guillaume Apollinaire (1880-1918) made another important step in the graphic revolution of verse. Calligraphy in East-Asian cultures is a variety of painting rather than of literature, while in Western-European cultures historically calligraphy had more to do with letters and writing. Besides, we should distinguish between ideographic and pictographic types of writing. In the latter, the relation of sign to object is of iconic nature, whereas in the former symbolicity overwhelms iconicity, that is relation not only to an object, but also to an idea. Apollinaire seems to have merged these two traditions and two ways of writing in his reformation of European prosody. Katherine Shingler (2011) rightfully argues that Calligrams involve visual-verbal simultaneity on the part of the reader, making the textual and the pictorial aspects of the poem indissociable. The same holds true for the visuo-phonic correlation of ideograms, as Anna Whiteside-St Leger Lucas (1990) pointed out.

Apollinaire's Calligrams fall into two basic types: those set typographically and those drawn by hand. In this respect, translations of Calligrams into other languages are faced with a dilemma: should one translate all of them or only a part of them? It would seem that only the typographical calligrams are translatable, whereas the hand-drawn stand closer to painting and thus do 

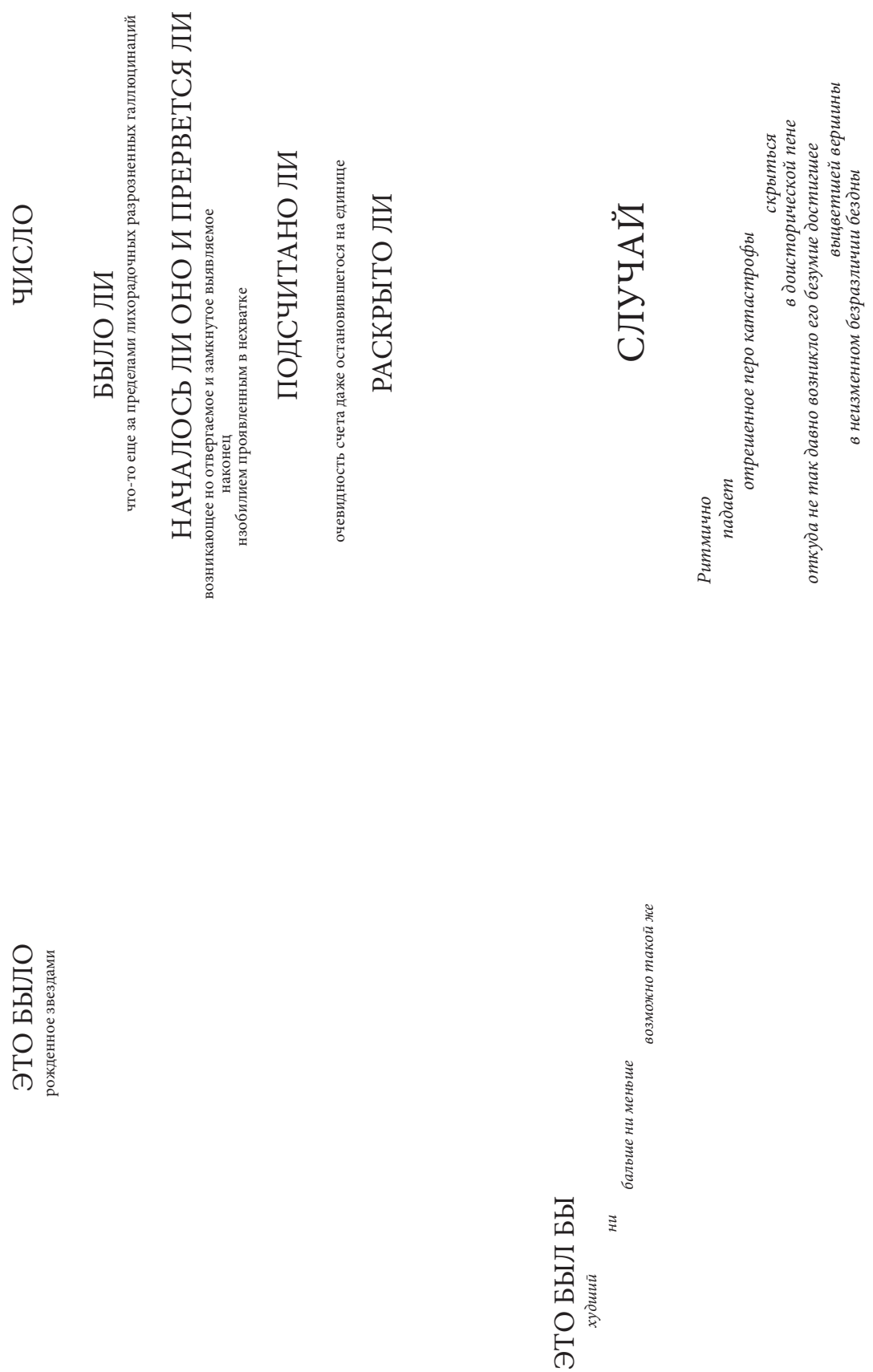

Figure 1. Stéphane Mallarmé, coup de dès, translated into Russian by Kirill Korchagin 


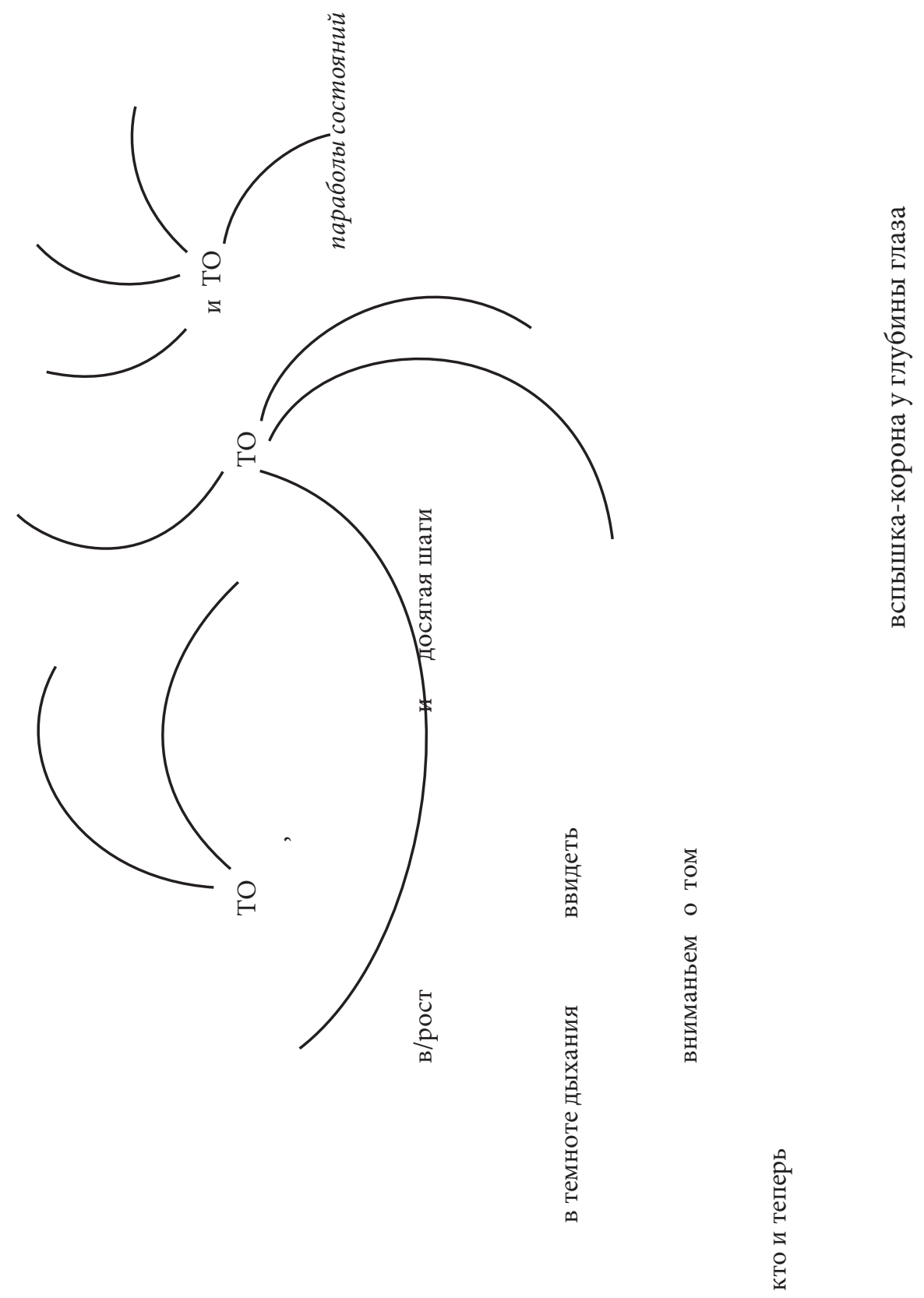

Figure 2. A fragment of Ivan Sokolov's visual poem 
not require translation. For example, the poem The Bleeding-Heart Dove and the Fountain lends itself to translation, as the Russian version proves, see Figures 3 and 4 .

\section{LA COLOMBE POIGN.IRDEE ET LE JET D'EAU}

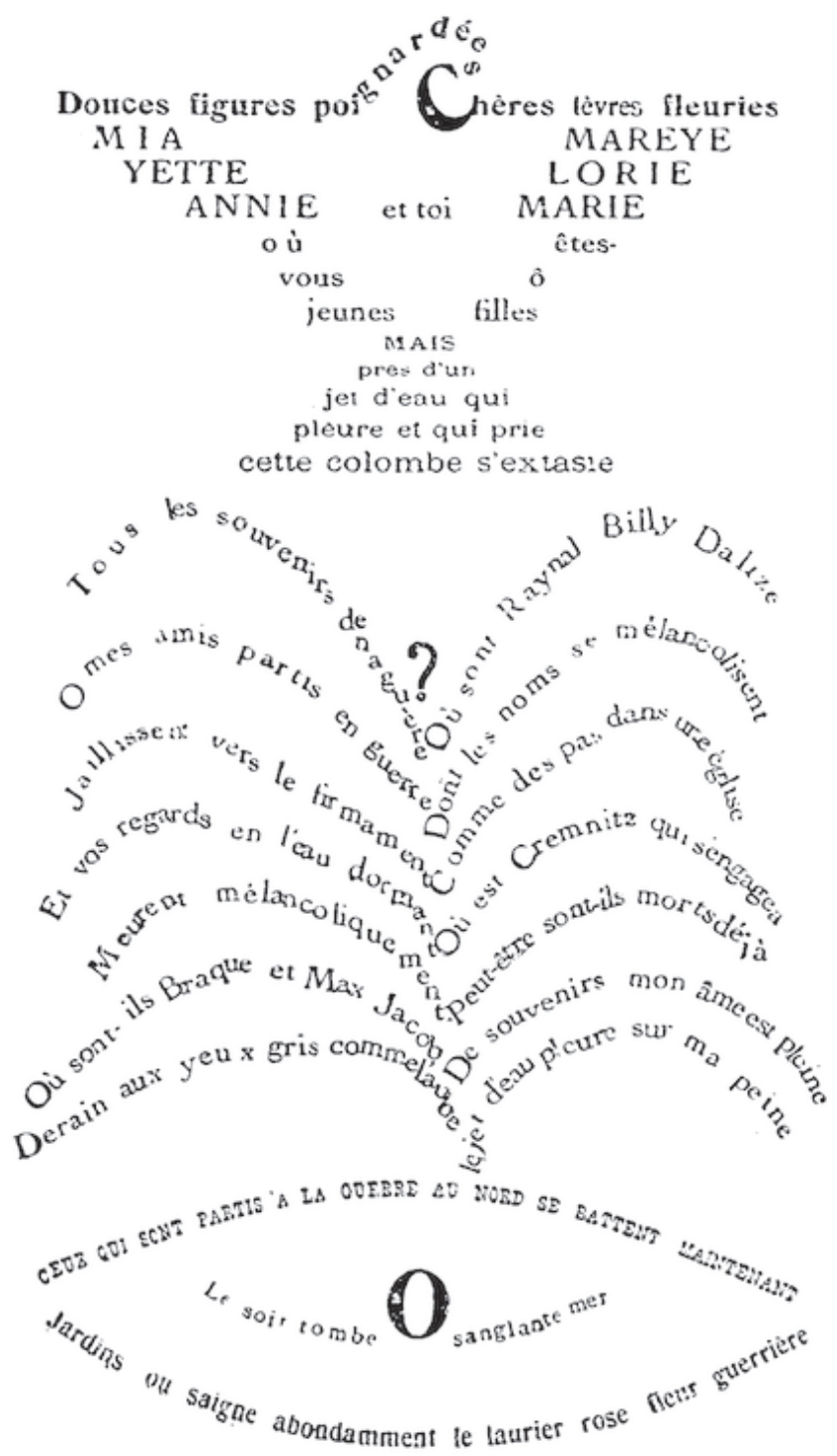

Figure 3. Guillaume Apollinaire, La colombe poignardée et le jet d'eau 


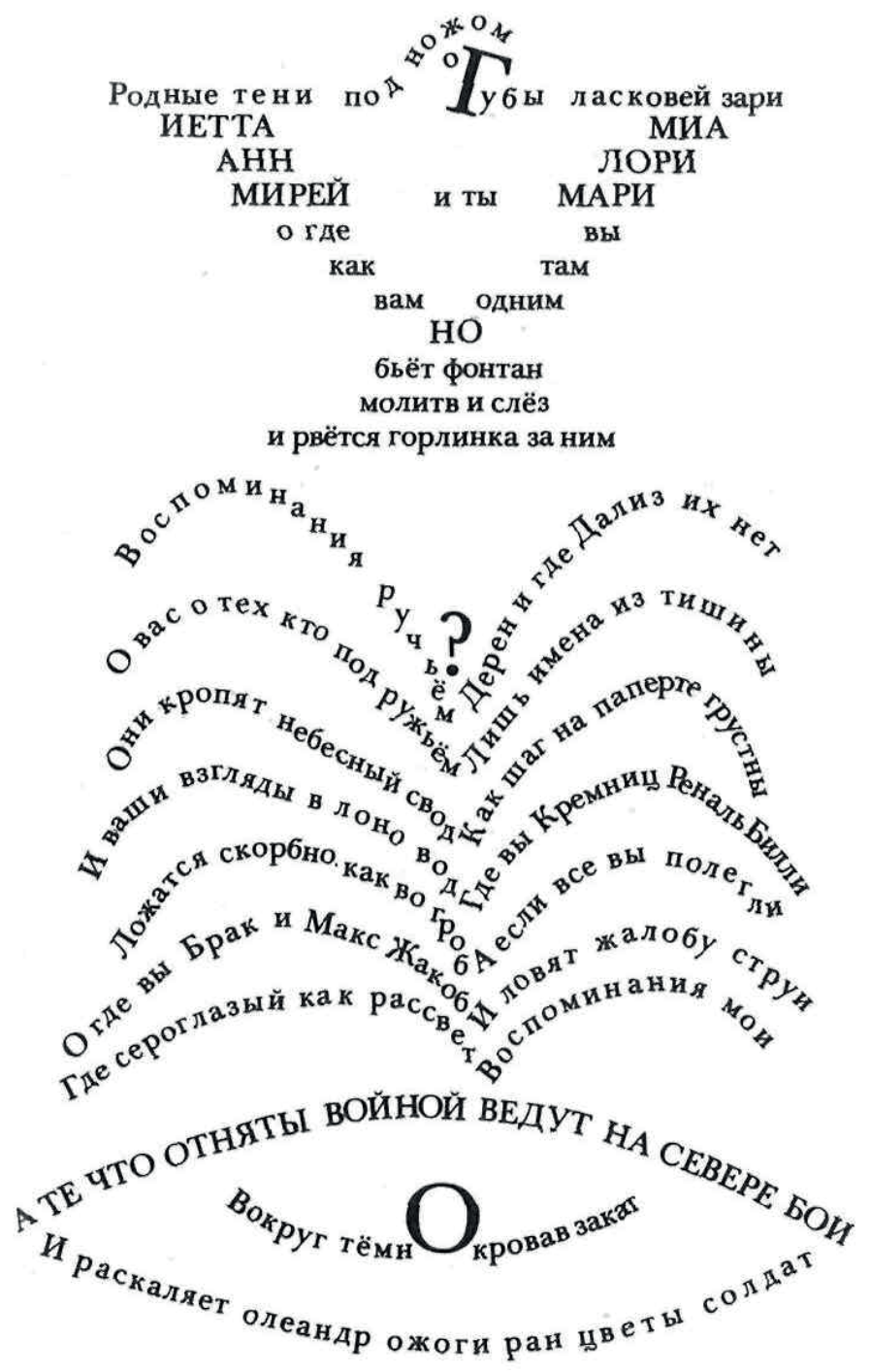

Figure 4. Guillaume Apollinaire, La colombe poignardée et le jet d'eau in Russian translation

The English translation of Eiffel Tour, a poem exploiting complex translingual play, follows the same principle of language affinity in terms of iconicity, see Figure 5. 


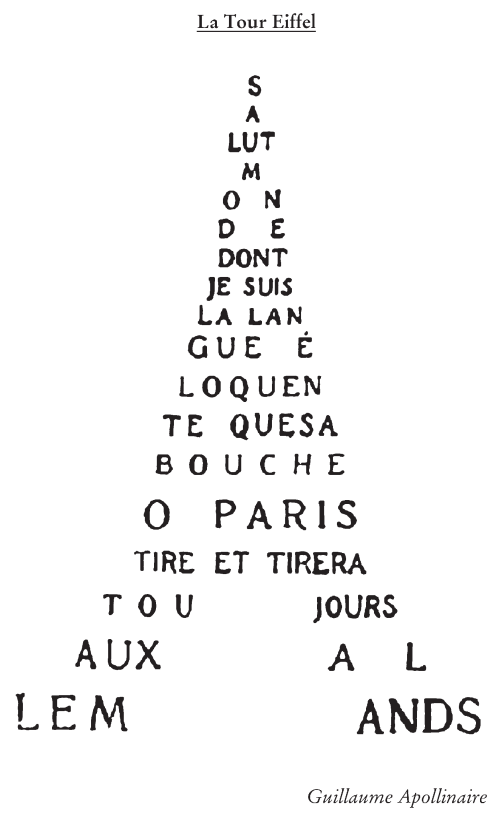

The Eiffel Tower

G

RE

ETIN

GS

E

A $\mathbf{R}$

T $\mathrm{H}$

$\mathrm{OF}$

WHICH

I AM THE E

LOQU

ENT TONGUE

WHICH POKES

FROM YOUR MOUTH

O P A R I S

AND W I LL P O K E

FOR

EVER

A $\mathrm{T}$

THE

GER

MANS

Translated from the French

by Claudia Habergham

Figure 5. Guillaume Apollinaire, La Tour Eiffel, English translation by Claudia Habergham

In these cases the text's spatial design is transferrable and the language of the poem translatable. Therefore, using Nelson Goodman's (1976) terms, we should distinguish between two types of texts: the autographic and the allographic. The autographic (hand-drawn) text, similarly to painting, is not translatable as a whole, while the allographic (typeset) allows for verbal code switching to more or less cognate languages.

The hand-drawn calligrams (see Figures 6 and 7) could also hypothetically be translated, but that would require at least a redrawing of the author's handwriting and would be a case of intersemiotic transposition (using Roman Jakobson's term) rather than mere translation. Of course, we can always translate the text of the autographic calligram, but not the entire body of the poem. As in case of any picture or painting, this kind of calligram needs not to be translated, as it is based primarily on the extralinguistic properties of signs and images. 


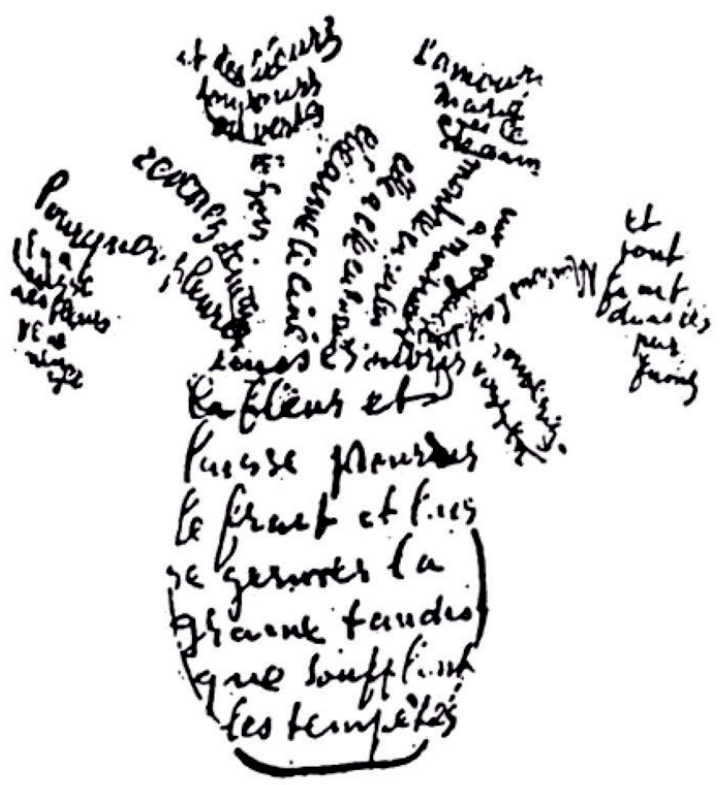

Figure 6. Guillaume Apollinaire, Fleurs

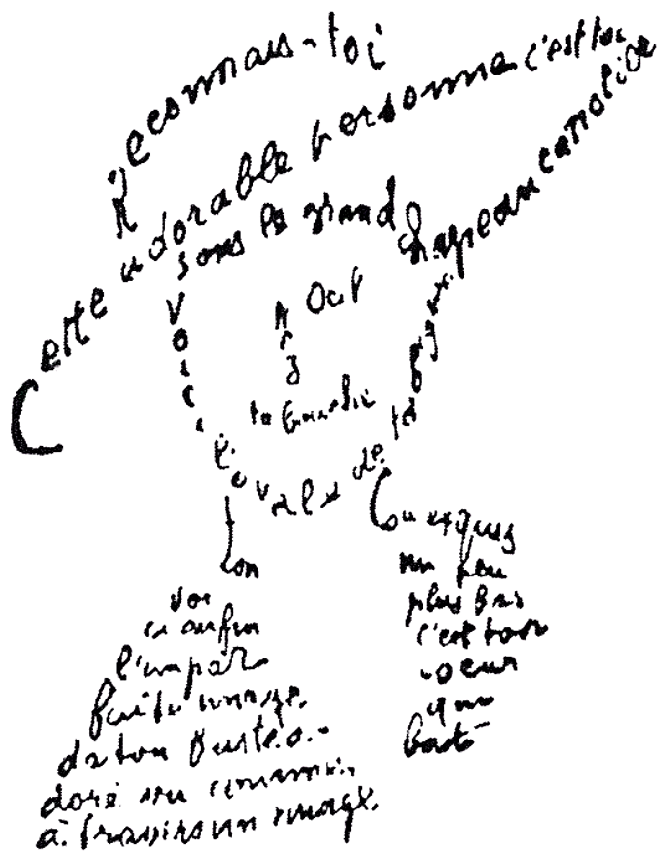

Figure 7. Guillaume Apollinaire, Poème du 9 février 1915 
The same dilemma persists in concrete and visual poetry of later times. Again, we are dealing with two major types of texts. The first prioritizes the verbal matter, and in this case, translation is possible and may be productive for the target language (e. g., in texts by Brazilian poets Haroldo and Augusto de Campos, see Figures 8 and 9). The second follows the pictographic, or analogic, principle (e. g. in more intricate 'versograms' by the Russian conceptualist poet Dmitry A. Prigov, see Figure 10). Translation of this type of texts is unlikely to add something to the original. Semantic augmentation only takes place in case of a different correlation between iconicity and symbolicity, which inevitably takes place in the target language.

speech

silver

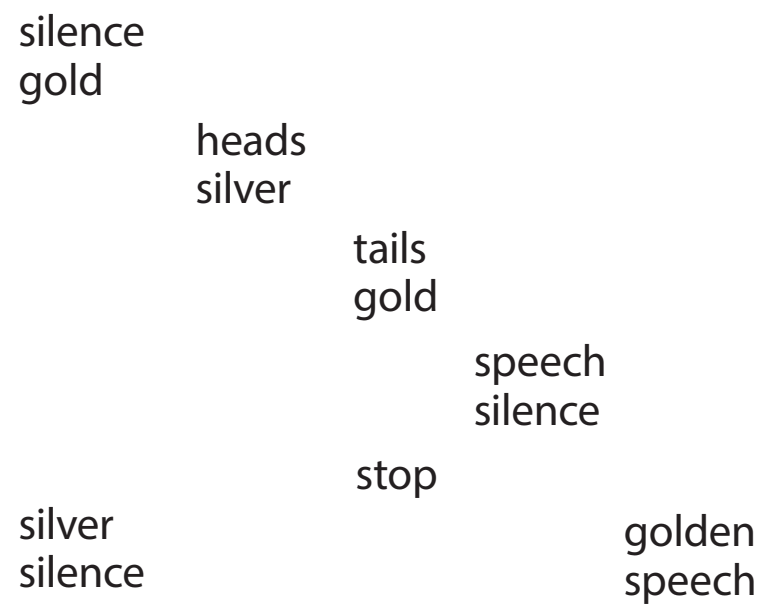

clarity

Figure 8. Haroldo de Campos, untitled poem 
c o I o c a r a ma s

c a r a c o l o c a $r$

a ma s c a r a col

o c a r a mas c a r

a c o I o c a r a ma

s c a r a col oc a

r a ma s c a r a co

I o c a r a mas c a

r a c o I o c a r a m

a s c a r a c o l o c

a $r$ a $n$ a c a $\mathbf{r}$ a

- I o c a r a ma s c

a r a c o I o c a $r$ a

ma s c a r a col o

c a r a mas c a r a 


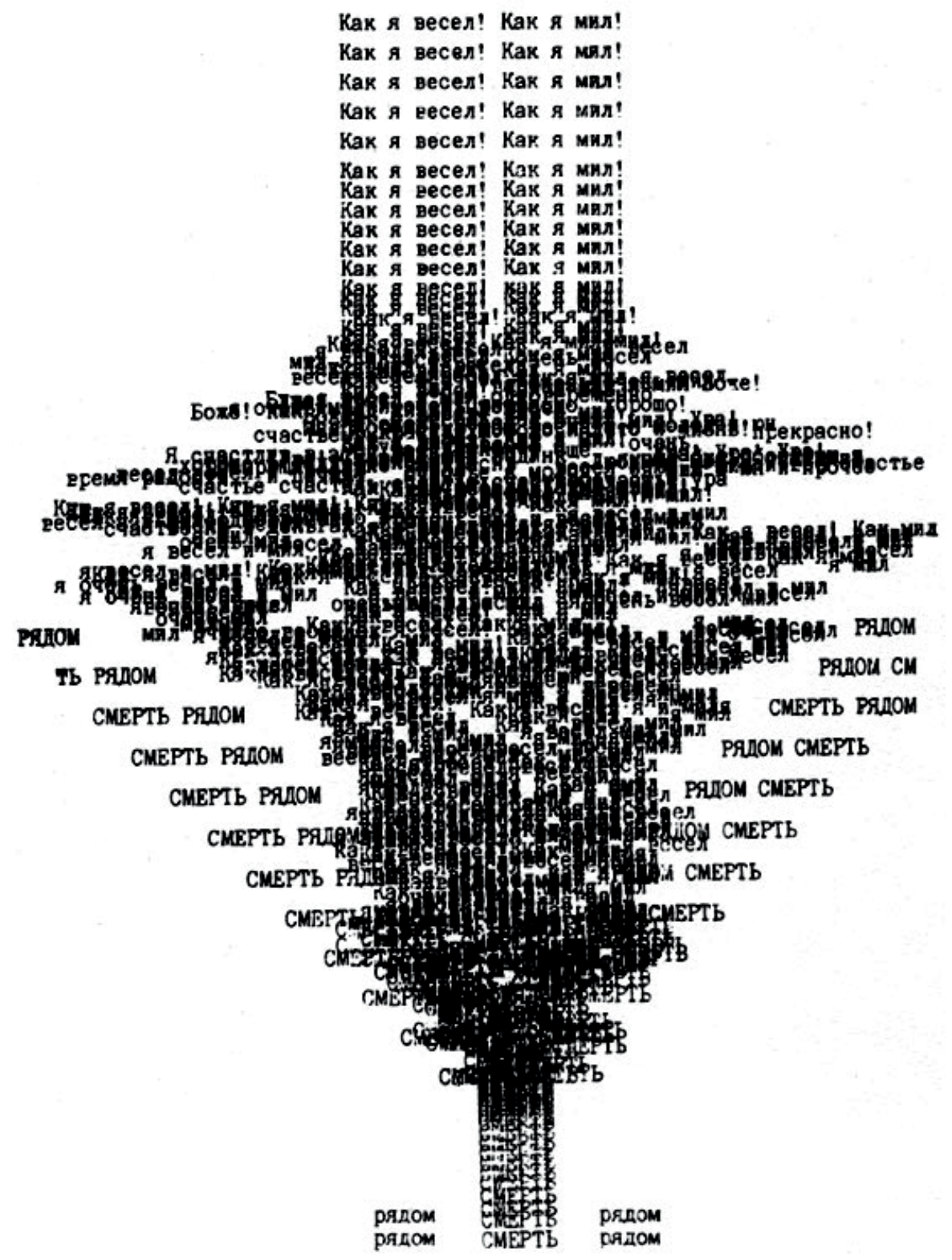

Figure 10. Versogram by Dmitry A. Prigov 


\section{E. E. Cummings' experimental verse: between 'graphic translation' and 'transcreation'}

Now we will discuss some examples of poems written by one author, where spatial design subtly interacts with verse's semantic structures, which in translation can activate linguistic processes of the target language. Alongside Apollinaire, the American poet E. E. Cummings (1894-1962) took up experiments with verse's visual form. In 1916-1917, he already composed poems such as sky was candy. This poem exists in two variants. Curiously, the first variant published posthumously from the manuscripts, seems and looks freer than the final one and resembles Mallarmés word constellations. In the initial version of the poem, he arranges words and parts of words in a scattered fashion. Its reading is not linear any more. Furthermore, the words constitute a visual shape suggesting something of a portrait or an image of the flower. The second version, published in 1923, is already an adaptation to printed page; the spatial design is different here. The original manuscript variant might have seemed too freestyle either to the author himself, or to his publishers, see Figures 11 and 12.

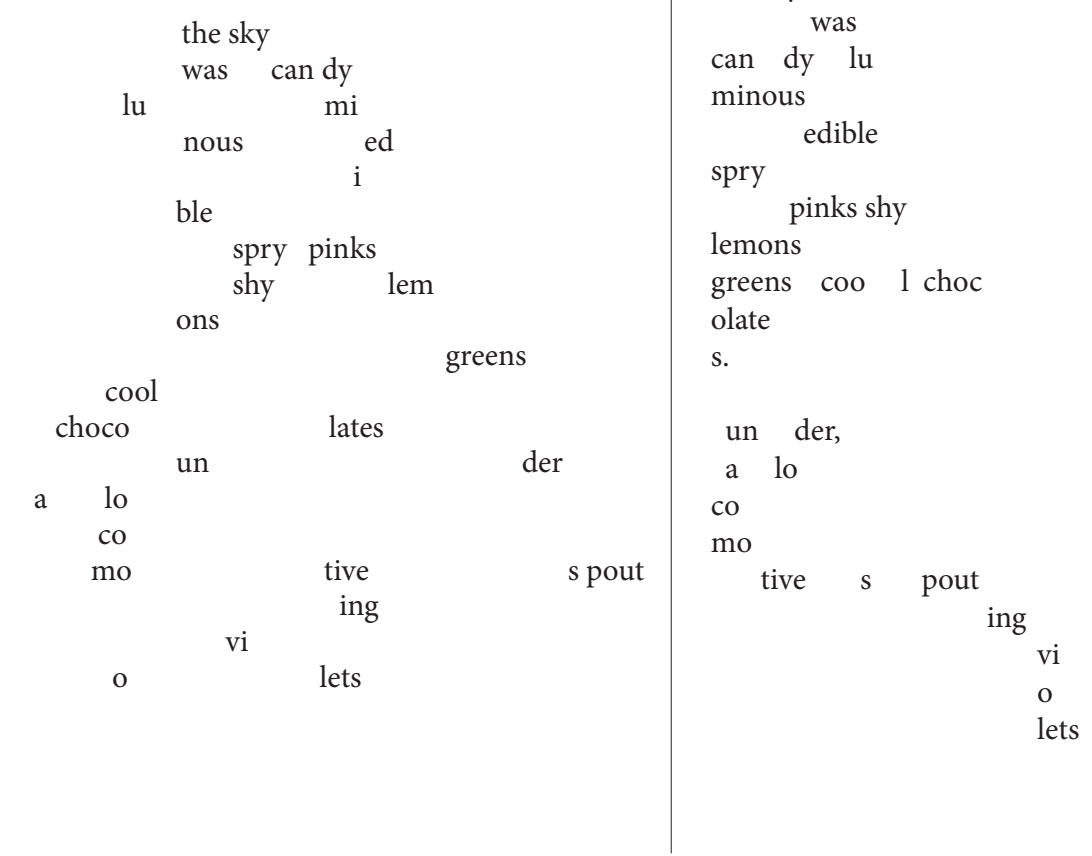


One of Cummings' spatial design masterpieces is his 1932 poem known as grasshopper. Let us take a closer look at how the iconic and other semiotic planes interact in this text in terms of its translatability into other national languages. The text is evidently iconic. Rather than writing a poem about a grasshopper, the author, who was a "poet-and-painter" in his own words, literally draws a grasshopper graphically on the page, as a graph by Max Nänny (1985) schematically shows it, see Figures 13 and 14:

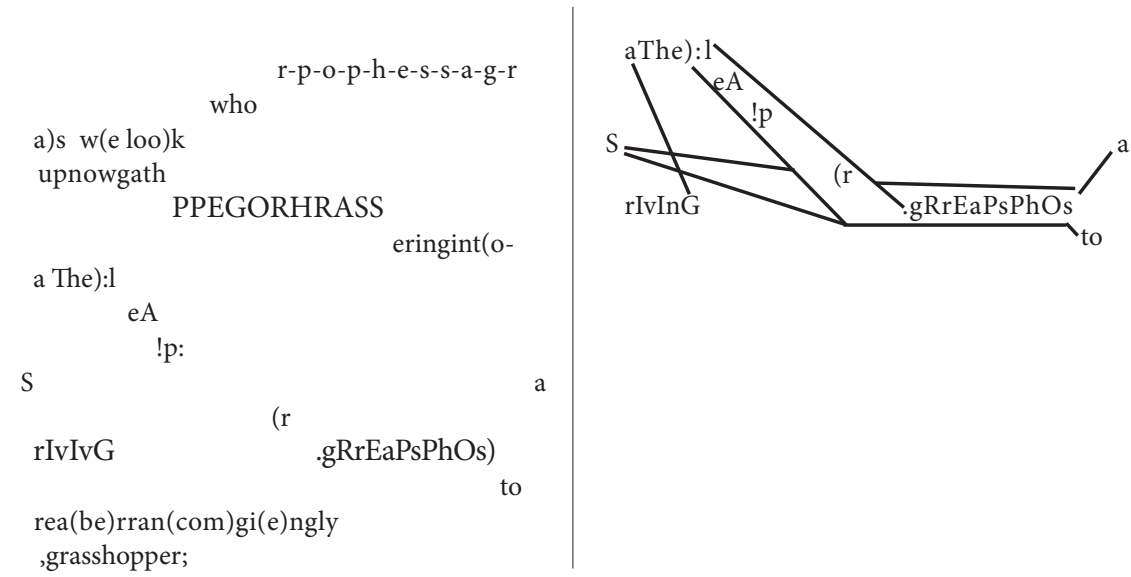

Figure 13. E. E. Cummings, Grasshopper Figure 14. A graph by Max Nänny

Cummings goes even further than that. To convey iconically the image of a grasshopper it would be enough to confine to this figurative and bodily portrayal. Cummings renders the activity of a grasshopper in writing, specifically combining the letters and sounds in verse. Indeed, the poem acts as a mimicry of the becoming and rearranging grasshopper in the movement of speech, in its articulations and dismemberments, in the abruptness of leaps, in the recomposition of the word by analogy with the body of the insect. The effect of this poem is not in its imitative or life-like nature, characteristic of figurative painting, but in its transsemiotic performativity where the very punctuation of typographical signs creates an equivalent of the object of representation. The poem ceases to be just a poem, transformed into poiesis as an event of the poem's creation.

It is interesting how Cummings worked on this poem and its publication. The recent archival publications have revealed (see Webster 2013) that he meticulously elaborated each graphic and linguistic detail of the poem, up to the point where he even drew a grid over the text. Each word, part of word, letter, mark, character, space, indent, arrangement of words between 
each other occupied a particular cell in that grid resembling the periodic system of elements. For his personal typesetter he made a detailed analysis of each element of the text. He also gave instructions to his Brazilian translator Haroldo de Campos. Translation into Portuguese was one of the first for this poem, followed by translations into French, German, Dutch, Russian, and other languages, see Figures 15, 16, 17 and 18.

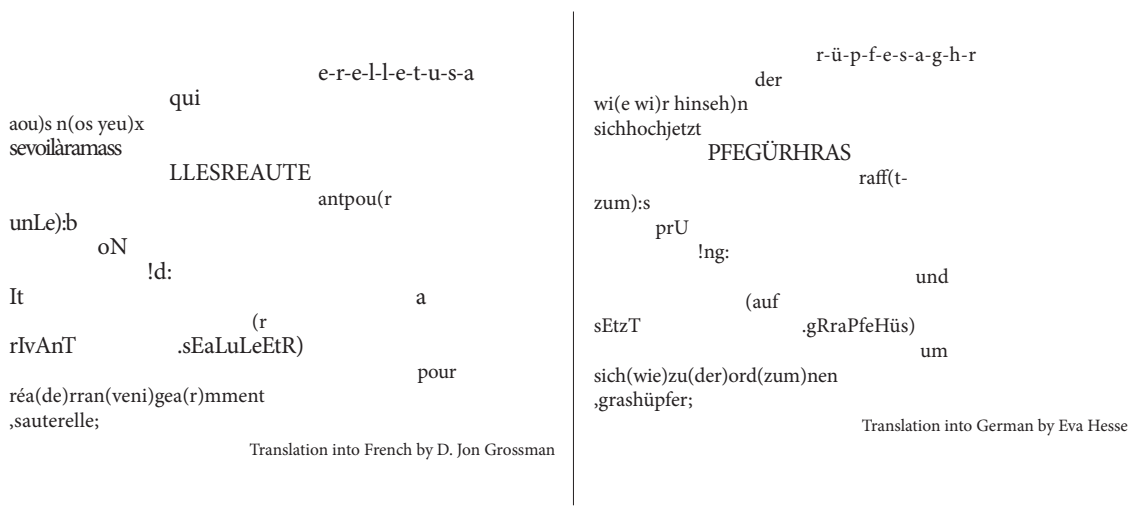

Figure 15. E. E. Cummings, Grasshopper,

Figure 16. E. E. Cummings, Grasshopper, translated into French by D. Jon Grossman

translated into German by Eva Hesse

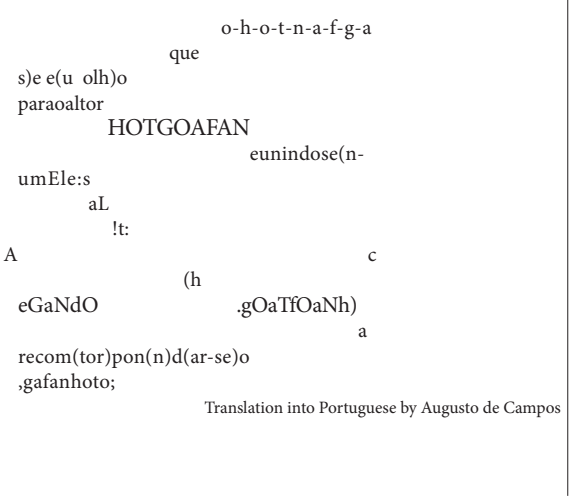

Figure 17. E. E. Cummings, Grasshopper, translated into Portuguese by Augusto de Campos

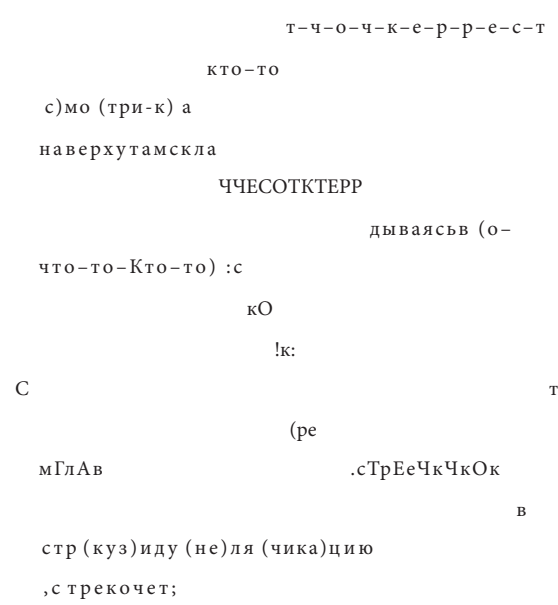

Figure 18. E. E. Cummings, Grasshopper, translated into Russian by Vladimir Feshchenko 
In each of these versions, the translator seeks to bring all text levels together - iconic, phonic, and symbolic. The iconic level constitutes the spatial design of the poem; the phonic level reproduces the sound structure of the text; and the symbolic level makes the other two interact with the semantics of this verse. The Russian translator (Vladimir Feshchenko) intentionally chose the Courier New font because it allows making a regular grid measuring links between lines, letter, and characters. In fact, this font is the closest approximation to the mono-width spacing of the typewriter and Cummings himself advocated for this typewriter advantage, as Michael Webster (2013) has clearly shown. Figure 18 is not the only Russian translation of this poem. Another, better-known one, by Vladimir Britanishsky (see Figure 19), does not take account of all levels of the text involved (see more on Russian translations of this poem in Janecek 2000. Moreover, the other translator chose the Russian word сверчок (cricket) as equivalent to grasshopper, which appears strange both formally and semantically. The length of the equivalent should be around eleven letters, сверчок has only seven and it actually signifies a different kind of insect. The newer translation uses the word стридуляция (stridulation) as having exactly the same number of letters, sounding more like grasshopper and actually signifying the sound produced by a grasshopper.

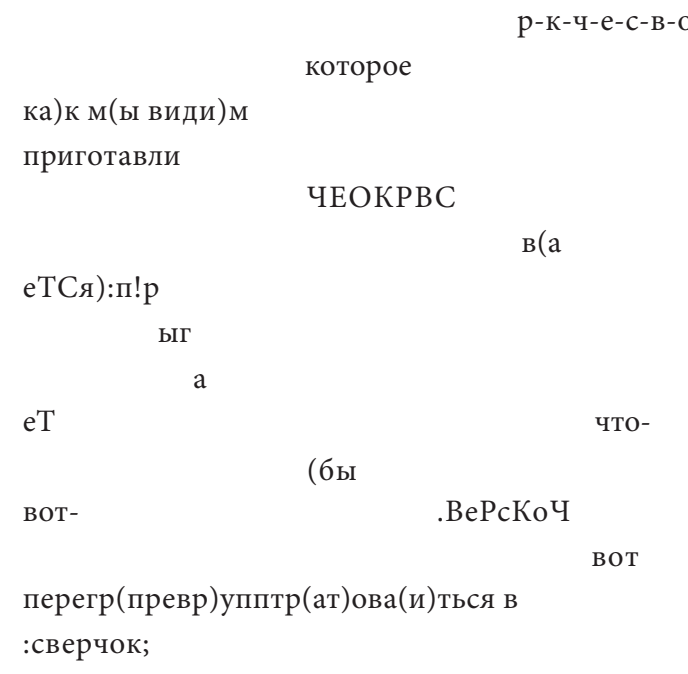

Figure 19. E. E. Cummings, Grasshopper, transl. into Russian by Vladimir Britanishsky 
The problem of interaction between the graphic and linguistic levels of verse arises in translating somewhat different poems by E. E. Cummings, too. For example, in translating the poem $f l$ into Russian, the challenge is this. If the verse reduces itself to exquisite interplay of short egocentric words, such as articles, pronouns, prepositions, which in their turn disintegrate into yet smaller pieces of speech, is it possible to find translated equivalents to this interplay while preserving the graphic, sonic and semantic qualities of the source text? The point here is not about mere iconicity like in Apollinaire's calligrams. It would seem that the two languages could expose a kind of structural isomorphism between deictic and phonetic devices. The translator needs to undertake a similar procedure of rearrangement of egocentric words, not literal but isomorphic. Instead of using exact equivalents to such words as I, $m y$, he, them, we, that, in, on, is, are etc. on their identical positions in the poem's space, the translator rearranged them across the text to preserve the graphic structure and at the same time to convey the deictic effects of Cummings' poem. The target version in this case gravitates as much as possible towards the chopped-word lengths of source lines, at the same time reproducing the disintegrated subjectivities of the source text. Pronouns or similar words broken into shorter pronouns (wait $\rightarrow$ wa / it; $s p i t \rightarrow s p / i / t$; these $\rightarrow t /$ he / s /e) acquire different but deictically identical equivalents in the Russian version (спрямленные $\rightarrow$ спр / я / мле / нные; вон те $\rightarrow$ в / он / те; бормы $\rightarrow$ ф / ор op / мы). Similarly to the reader of the text in English, the translator not only looks at the poem, but performs an assembly of its disintegrated grammatical texture, see Figure 20 (hereinafter all translations of E. E. Cummings' poems into Russian are by the author).

The subject of another Cummings' poem, known as $l(a$, is the Self's loneliness assimilated to the loneliness of a leaf falling from a tree. The word $I$ at the top of the poem may also read as the numeral 1 and the first line together as the French definite article la. The word one below and the neologism iness at the bottom of the poem intensify the meaning of oneness. In Russian, the translator used somewhat different signs, e. g. the Roman numeral $I$ that coincides graphically with the English pronoun I. Instead of translating loneliness into the exact Russian одиночество, the translator opted for the neological participle одиночествуя, which contains in itself three markers of subjectivity: один (one), оче (еуе), $я$ (I). Оче in this experimental usage may read as an appellative case of the word око mеaning "еуе as sight organ", see Figure 21 (see more on E. E. Cummings' experiments with verbal and pictorial deixis in Feshchenko 2015) 


\begin{tabular}{|c|c|}
\hline спр & $\mathrm{fl}$ \\
\hline я & $\mathrm{a}$ \\
\hline мле & $\mathrm{tt}$ \\
\hline нные & ene \\
\hline $\mathrm{cc}$ & $\mathrm{d} d$ \\
\hline $\mathrm{OHH}$ & \\
\hline ост & $\begin{array}{l}\text { reaml } \\
\text { essn }\end{array}$ \\
\hline и & esse \\
\hline суть & s wa \\
\hline 6 & it \\
\hline esch & $\mathrm{sp}$ \\
\hline $\mathrm{a}$ & $\mathrm{i}$ \\
\hline и по & $t)(t$ \\
\hline дожди & he \\
\hline бры & s \\
\hline $\mathrm{s \Gamma}$ & $\mathrm{e}$ \\
\hline и)(и & $\mathrm{f}$ \\
\hline B & \\
\hline $\mathrm{OH}$ & ooli \\
\hline те & $\begin{array}{l}\text { sh sh } \\
\text { apes }\end{array}$ \\
\hline несу & \\
\hline $\begin{array}{l}\text { разные } \\
\phi\end{array}$ & ccocoucougcoughcoughi \\
\hline op op & ng with me \\
\hline мы & $\begin{array}{l}\mathrm{n} \text { more } \mathrm{o} \\
\mathrm{n} \text { than in the }\end{array}$ \\
\hline ччичихчиха & $\mathrm{m}$ \\
\hline $\begin{array}{l}\text { я со моим } \\
\text { и больше на } \\
\text { них чем в н }\end{array}$ & \\
\hline
\end{tabular}

Figure 20. E. E. Cummings, fl, translated into Russian by Vladimir Feshchenko 


\begin{tabular}{|c|c|}
\hline I(один & l(a \\
\hline ли & le \\
\hline $\mathrm{CT}$ & af \\
\hline па & fa \\
\hline да & ll \\
\hline ет) & $\begin{array}{l}\text { s) } \\
\text { one }\end{array}$ \\
\hline один & 1 \\
\hline оче & \\
\hline ству & iness \\
\hline
\end{tabular}

Figure 21. E. E. Cummings, I (a, translated into Russian by Vladimir Feshchenko

Based on the analyzed examples of translations from Mallarmé, Apollinaire and Cummings we could propose a new term for rendering the spatial design of a poem in another language. By analogy with "phonemic translation" (a term introduced in Lefevere 1975) and "phonetic translation" (as exhaustively described in Pilshchikov 2016), which preserves the sound texture of the poem sometimes at the expense of semantic fidelity, we would suggest to use the term graphic translation. This type of translation preserves the visual and metagraphemic forms of the original text, rearranging its lexical elements in translation. Graphic translation specifically applies to visually-oriented avant-garde and experimental texts. This translation strategy is opposite to still another one, when the target text in a different language preserves the inner form of the original but appears in different metagraphemics. Such is the example of Giuseppe Ungaretti's (1888-1970) poem Voyage self-translated by the author from Italian into French, see Figure 22. 


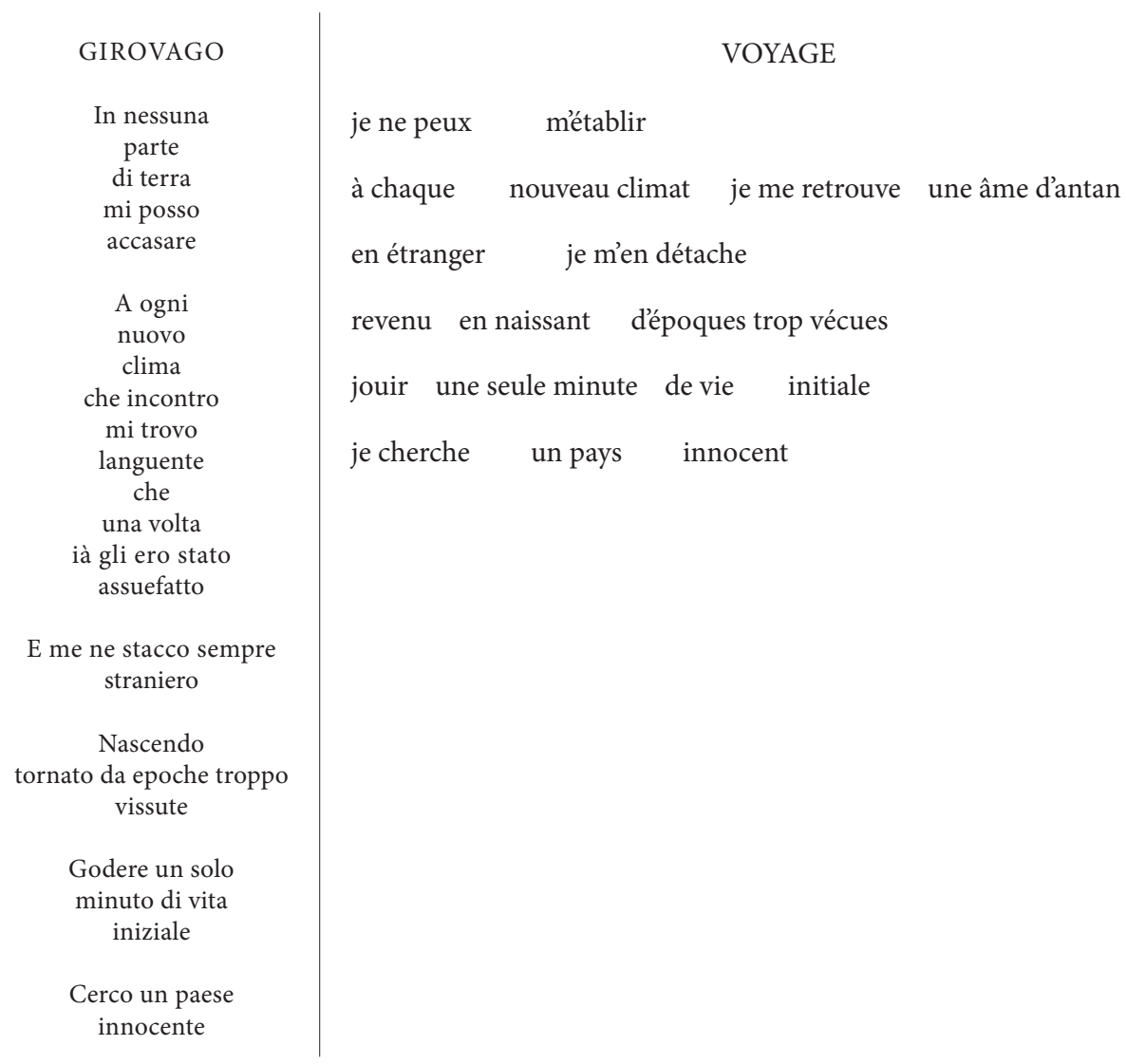

Figure 22. Giuseppe Ungaretti, Voyage

In the French version, as we can see, the verse is more inclined towards the Mallarméan tradition of free verse which reads vertically and diagonally, or even recursively, rather than horizontally. However, this is a specific case of self-translation, where the author is freer in his means than a regular translator is.

Both of these strategies fall within a more general approach to poetry translation called "transcreation" by the Brazilian poet and translator Haroldo de Campos. In his essay On Translation as Creation and Criticism he argued, "Every translation of a creative text will always be a "re-creation", a parallel and autonomous, although reciprocal, translation - 'transcreation'. The more intricate the text is, the more seducing it is to 're-create' it. Of course, in a translation of this type, not only the signified but also the sign itself is translated, that is the sign's tangible self, its very materiality (sonorous properties, 
graphical-visual properties, all of that which forms, for Charles Morris, the iconicity of the aesthetic sign [...]). The signified, the sematic parameter, becomes just a kind of boundary marker for the 're-creative' enterprise. We are, then, at the opposite end of the 'spectrum' from the so-called literal (or servile) translation" (2007: 315). Graphic translation 'transcreates' the text to a certain degree, and this, as we have argued, contributes to preserve and reinforce the experimental nature of avant-garde verse in languages other than its own.

\section{References}

De Campos, Haroldo 2007. On Translation as Creation and Criticism. In: De Campos, Haroldo, Novas. Selected Writings. Evanston, IL: Northwestern University Press, 312-326.

Fateeva, Natalia 2010. Metagrafemika kak otrazhenie avangardnogo myshlenija [Metagraphemics as Expression of Avant-Garde Thought]. In: Russian Literature 67(3/4), 303-317.

Feshchenko, Vladimir 2015. Telesnyj deiksis v eksperimentalnoj poezii: opyt E. E. Kammingsa [Bodily deixis in experimental poetry: a case of E. E. Cummings]. In: Novoe literaturnoe obozrenie 135, 43-55.

Goodman, Nelson 1976. Languages of Art: An Approach to a Theory of Symbols. Indianapolis: Hackett Publishing Company.

Janecek, Gerald 2000. Tri kuznechika: Khlebnikov, Kammings, Ajgi [Three grasshoppers: Khlebnikov, Cummings, Ajgi]. In: Prżegląd Rusycystyczny 1/89, $22-33$.

Kenesei, Andrea 2010. Poetry Translation through Reception and Cognition. The Proof of Translation Is in the Reading. Cambridge: Cambridge Scholars Publishing.

Kristeva, Julia 1974. La révolution du langue poétique: l’avant-garde à la fin du XIXe siècle: Lautréamont et Mallarmé. Paris: Seuil.

Lefevere, André 1975. Translating Poetry: Seven Strategies and a Blueprint. Assen: Van Gorcum.

Mallarmé, Stéphane 2014. Brosok kostej [A Roll of the Dice]. Translated into Russian by Kirill Korchagin. In: Nosorog 1, 153-175.

Mallarmé, Stéphane 2015. A Roll of the Dice. Translated into English by Jeff Clark and Robert Bononno. Seattle, Washington: Wave books. 
McCoy, Katherine 1988. Graphic Design: Sources of Meaning in Word and Image. In: Word \& Image 4(1), 116-130. https://doi.org/10.1080/02666286.1988.10436227

Nänny, Max 1985. Iconic Dimensions in Poetry. In: Waswo, Richard (ed.), On Poetry and Poetics. Tübingen: Gunter Narr, 111-137.

Nänny, Max 1986. Iconicity in Literature. In: Word \& Image 2, 199-208. https://doi.org/10.1080/02666286.1986.10435344

Perloff, Marjorie 2010. Unoriginal Genius: Poetry by Other Means in the New Century. Chicago: University of Chicago Press.

Pilshchikov, Igor 2016. The Semiotics of Phonetic Translation. In: Studia Metrica et Poetica 3(1), 53-104. https://doi.org/10.12697/smp.2016.3.1.03

Shingler, Katherine 2011. Perceiving Text and Image in Apollinaire's Calligrammes. In: Paragraph 34(1), 66-85. https://doi.org/10.3366/para.2011.0006

Venuti, Lawrence 2011. Introduction. Poetry and Translation. In: Translation Studies 4(2), 127-132. https://doi.org/10.1080/14781700.2011.560014

Webster, Michael 2013. Plotting the Evolution of a r-p-o-p-h-e-s-s-a-g-r. In: Spring: The Journal of the E. E. Cummings Society 20, 116-143.

Whiteside-St Leger Lucas, Anna 1990. Apollinaire’s Ideogrammes: Sound, Sense... and Visible Signs. In: Word \& Image 6(2), 163-179.

https://doi.org/10.1080/02666286.1990.10435427 